\title{
Synthesis, Characterization, In-vitro and In-silico Studies of 5,5-dimethyl-3-(phenylamino)-cyclohex-2-enone
}

\author{
Prabha Balakrishnan 1, Ezhilarasi Muthuvel Ramanathan 1,* (D) \\ 1 Department of Chemistry, Karpagam Academy of Higher Education, Coimbatore, 641 021, Tamil Nadu, India \\ * Correspondence: mrezhilarasi@gmail.com;
}

Scopus Author ID 14043431700

Received: 30.09.2020; Revised: 22.10.2020; Accepted: 23.10.2020; Published: 25.10.2020

\begin{abstract}
The present study reveals that the greener synthesis, in-silico, and in-vitro studies of 5,5dimethyl-3-(phenylamino)-cyclohex-2-enone (DMPC) derivatives. The solvent-free method is one of the most adorable methods for current environmental situations. It is one of the safe and ecological methods to synthesize cyclohex-2-enone compounds in the presence of sodium bisulfate used as a catalyst. It is highly economical. The synthesized cyclohexenone compounds are structure elucidated with the help of IR, ${ }^{1} \mathrm{H}$ and ${ }^{13} \mathrm{C}$ NMR values. All the DMPC (1-5) compounds have a good number of H-bond interactions with notable interaction scores. DMPC-1 has one H-bond interaction with an interaction score $-6.7 \mathrm{~kJ} / \mathrm{mol}$. DMPC-4 has four H-bond interactions and two hydrophobic interactions with an interaction score $-7.5 \mathrm{~kJ} / \mathrm{mol}$. DMPC-5 also has $-7.5 \mathrm{~kJ} / \mathrm{mol}$ as an interaction score with three $\mathrm{H}$-bond interactions and one hydrophobic interaction. Only the compound DMPC-4 has a good binding score with $1 \mathrm{JIJ}$. The binding score value is $-8.4 \mathrm{~kJ} / \mathrm{mol}$; this is the only value nearer to the standard drug binding score than other compounds. All the compounds have good interaction with 1UAG bacterial protein than interact with $1 \mathrm{JIJ}$ bacterial protein. This interaction study revealed that the DMPC (1-5) compounds follow the cell wall synthesis mechanism when treated with bacterial strains. The catalyst sodium bisulfate is a re-useable one for the synthesis process.
\end{abstract}

Keywords: cyclohex-2-enone; microwave; auto dock irradiation.

(C) 2020 by the authors. This article is an open-access article distributed under the terms and conditions of the Creative Commons Attribution (CC BY) license (https://creativecommons.org/licenses/by/4.0/).

\section{Introduction}

Present decade, Microwave irradiation methods are mostly followed to reduce the hazards and production of greenhouse gases during organic synthesis [1]. The most important source for heating purposes is the microwave oven [2]. The microwaves are used to synthesize organic compounds with reduced reaction time and improve in the yield, selectiveness process [3]. The organic synthesis is done by microwave, also known as an environmentally friendly process, with cleanliness associated solvent and wastes free process [4]. The many enamines are synthesized by using the microwave irradiated method [5-7].

The inherent structure features of dimethyl substituted cyclohexanone form several reactive centers in its ring; the reactive positions are $\mathrm{C}-1, \mathrm{C}-2$, and less extent to $\mathrm{C}-6, \mathrm{C}-3$. $\beta$ enamines is one of the best class of enamines with high stability [8]. Enamines are mostly stable because of its intermolecular $\mathrm{H}$-bond formation. The enamines form a $\mathrm{N}-\mathrm{C}=\mathrm{C}-\mathrm{C}=\mathrm{O}$ conjugation, which has high reactivity, enamines used as reactive intermediates in much synthetic organic chemistry to prepare many heterocyclic compounds [9-12]. The $\beta$-enamine also has a wide range of applications in various fields [13-15]. $\beta$-enamines has a significant 
pharmacological activity and exhibit mainly anticonvulsant activity [16-17]. Two methods simply synthesize these biological important and valuable $\beta$-enamines; one is the direct conventional method between the amine and 1,3-diketone with water removal by refluxing. The second method is transformation completed using activators such as microwave irradiation and other homogenous, heterogeneous catalysis [18-20]. $\beta$-enamines are effective intermediate on the synthesis of pharmaceuticals, amino acids, peptides, and alkaloids [21-22]. $\beta$-enamines are effectively synthesized by using n-number of catalyst.

In-silico studies are more economical and efficient methods to predict the pharmacokinetic properties of designed small organic moieties [23]. The combination of metabolics and transcriptomics information is simplified to identify the designed compounds' metabolic pathways by data processing method [24]. The molecular transfusion is one of the best methods to design and developed new compounds with improved affinity and potency compared with previous parent compounds [25]. In order to predict a safer and efficient drug candidate for designed organic molecules, the ADMET profile was raised too early stage estimation parameters [26]. Hence in-silico study helps one or more molecules with quick, predictive models access pharmacokinetics, physicochemical, and other drug-like parameters [27].Now, here shows that the synthesis of $\beta$-enamine via a microwave-assisted process using sodium bisulfate silicate is a catalyst. The present article also explains the structural elucidation, docking studies, ADME property, and in-vitro bacterial activity of the abovementioned compounds.

\section{Materials and Methods}

\subsection{Instruments.}

The organic inhibitor's skeleton structure was confirmed by using Perkin-Elmer 1650 spectrometer and Bruker AMX 400 NMR spectrometer. The Perkin-Elmer 1650 was used for IR studies with the absorption unit $\mathrm{cm}^{-1}$. Bruker AMX instrument was used to predict and carry out the ${ }^{1} \mathrm{H}$ and ${ }^{13} \mathrm{C}$ NMR values of the DMPC compounds with the unit ppm, and the standard was TMS, $\mathrm{CDCl}_{3}$, as a solvent. The single-mode microwave reactor was used for synthesis purposes under control pressure, temperature, and power. Maspec MSW 9629 spectrometer was used for obtaining the mass spectra value of the inhibitor.

\subsection{Procedure for synthesis of DMPC compounds.}

The chemical p-nitro aniline $(1 \mathrm{mmol})$ was taken in the Erlenmeyer flask $150 \mathrm{ml}$. The weighed $1 \mathrm{mmol}$ of dicarbonyl compound was added in the Erlenmeyer flask. It was introduced in a domestic microwave oven (godrej) and irradiated for 3-10 min (260 W).

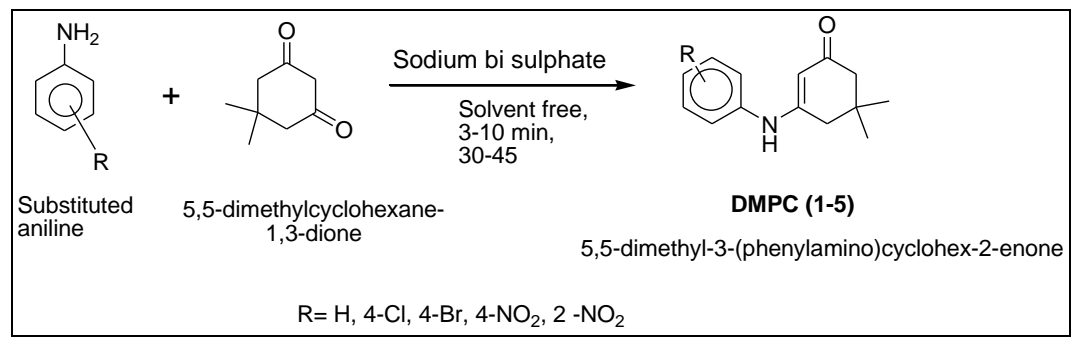

Figure 1.The microwave-assisted pathway of 5,5-dimethyl-3-(phenylamino)cyclohex-2-enones. 
The oven was turned off always after 3-minutes periods of heating to avoid evaporation of the reagents. The reaction was monitored by TLC, and after completion, the flask cooled, and the products were removed from the flask either by scratching or with a pipette and weighed for yields determination.

\subsection{Molecular docking.}

The Auto dock 4.2.5.1 version program was used for the molecular docking studies of synthesized DMPC derivatives. The given literary method was followed to find the docking scores [28].

\section{4. $A D M E$.}

The DMPC compound structure was subjected to absorption, distribution, metabolism, and excretion (ADME) study using the Swissadme online tool. The tool has the basic information about solubility (S), log P, polar surface area (TPSA), Hydrogen bond acceptor (Hd. Ac.), Hydrogen bond donor (Hd. Dn.), and other some of the basic information. The above parameters help understand the ADME property of any drugs or organic molecules. The compound has a drug property, which means it must obey the rule of five described by Lipinski. The Lipinski rules are: the compound must have Molecular weight $\leq 500$, Hydrogen bond acceptor $\leq 10$, hydrogen bond donor $\leq 5, \log p \leq 5$, and molar refractivity $\leq 140$. The other most important properties of the compound are that they have polar surface area range between 7 to $200, S$ range above -4 , the drug score value above 0.5 , and drug-likeness score as in positive values for synthesized organic compounds $[29,30]$. The percentage of absorption calculating by the known formula [31,32],

$$
\% \text { Abs }=109-0.345^{*} \text { TPSA }
$$

\subsection{Antimicrobial screening test.}

The disk diffusion method is used to carry out the antimicrobial studies of target DMPC compounds. Sterilized inoculums and sterile swabs were used. One negative and one positive strain were used for anti-bacterial screening. Ciprofloxacin was used as standard drugs in the microbial studies. Other steps were adopted from reference [33].

\section{Results and Discussion}

\subsection{Structural confirmation of the organic inhibitor.}

The DMPC target compounds were synthesized using Schiff base reaction between substituted aniline and 5,5- dimethyl substituted cyclohexan-1,3-dione via microwave irradiation. The microwave method is one of the best and eco-friendly to synthesize this type of organic inhibitors. It is also a time-saving, economical method. The skeleton structures were confirmed by using elemental analysis and spectral data's which were given below.

DMPC-1 (5,5-dimethyl-3-(phenylamino)cyclohex-2-enone): Yield 70\%, M.P $165^{\circ} \mathrm{C}$, Molecular Formula $\mathrm{C}_{14} \mathrm{H}_{17} \mathrm{NO}$; \%Calcd. (Found); $\mathrm{C} \%=78.00$ (78.10), $\mathrm{H} \%=7.93$ (7.96), N\% $=6.50(6.51), \mathrm{O} \%=7.36(7.43) . \mathrm{M} / \mathrm{z}(\mathrm{M})+: 215.3 ; \mathrm{FT}-\mathrm{IR}\left(\mathrm{KBr}, \mathrm{cm}^{-1}\right): 3042.09 \mathrm{~cm}-1$ (Aromatic $\mathrm{CH}$ stretching), $2889.54 \mathrm{~cm}^{-1}$ (Aliphatic $\mathrm{CH}$ stretching), $1656.67 \mathrm{~cm}^{-1}$ (Amide $\mathrm{C}=\mathrm{O}$ stretching), $1418.05 \mathrm{~cm}^{-1}\left(\mathrm{C}=\mathrm{N}\right.$ Stretching), 645.15, 735.42, $784.42 \mathrm{~cm}^{-1}$ (Aromatic ring stretching); ${ }^{1} \mathrm{H}$ $\mathrm{NMR}\left(\mathrm{CDCl}_{3}, \delta \mathrm{ppm}, 400 \mathrm{MHz}\right) 1.02-1.11\left(\mathrm{~m}, 6 \mathrm{H}\right.$ of $\left.\mathrm{CH}_{3}\right), 1.88-2.86(\mathrm{~m}, 4 \mathrm{H}$ of methylene in cyclohexanone), $3.62(\mathrm{~S}, 1 \mathrm{H}$ of $\mathrm{NH}), 5.54(\mathrm{~d}, 1 \mathrm{H}$ of $\mathrm{C}-2$ of cyclohexanone), 6.48- 
7.15(Aromatic protons); ${ }^{13} \mathrm{C} \mathrm{NMR}$ ( $\mathrm{CDCl}_{3}, \delta \mathrm{ppm}, 100 \mathrm{MHz}$ ): $198.93(\mathrm{C}=\mathrm{O}), 27.21$ (methyl group in cyclohexanone ring), 99.08 (C-2 of cyclohexanone), 162.35 (C-3 of cyclohexanone), 43.08 (C-4 of cyclohexanone), 31.59 (C-5 of cyclohexanone), 52.73 (C-6 of cyclohexanone), 122.56-144.08 (Aromatic carbons).

DMPC-2 (5,5-dimethyl-3-(4-chlorophenylamino)cyclohex-2-enone): Yield 72\%, M.P $278^{\circ} \mathrm{C}$, Molecular Formula $\mathrm{C}_{14} \mathrm{H}_{16} \mathrm{NOCl}$; \%Calcd. (Found); $\mathrm{C} \%=67.35$ (67.33), $\mathrm{H} \%=6.41$ (6.46), $\mathrm{N} \%=5.61(5.61) \mathrm{O} \%=6.41(6.41), \mathrm{Cl} \%=14.21(14.20) ; \mathrm{FT}-\mathrm{IR}\left(\mathrm{KBr}, \mathrm{cm}^{-1}\right): 3076.23 \mathrm{~cm}^{-}$ ${ }^{1}$ (Aromatic CH stretching), $2888.45 \mathrm{~cm}^{-1}$ (Aliphatic $\mathrm{CH}$ stretching), $1652.25 \mathrm{~cm}^{-1}$ (Amide $\mathrm{C}=\mathrm{O}$ stretching), $1412.51 \mathrm{~cm}^{-1}\left(\mathrm{C}=\mathrm{N}\right.$ Stretching), 654.15, 710.54, $783.91 \mathrm{~cm}^{-1}$ (Aromatic ring stretching); ${ }^{1} \mathrm{H}$ NMR $\left(\mathrm{CDCl}_{3}, \delta \mathrm{ppm}, 400 \mathrm{MHz}\right)$ 1.03-1.25 (m, $6 \mathrm{H}$ of $\left.\mathrm{CH}_{3}\right), 2.14-2.84(\mathrm{~m}, 4 \mathrm{H}$ of methylene in cyclohexanone), $3.62(\mathrm{~S}, 1 \mathrm{H}$ of $\mathrm{NH}), 5.68$ (d, 1H of C-2 of cyclohexanone), 6.45-7.87(Aromatic protons); ${ }^{13} \mathrm{C} \mathrm{NMR}\left(\mathrm{CDCl}_{3}, \delta \mathrm{ppm}, 100 \mathrm{MHz}\right): 198.82(\mathrm{C}=\mathrm{O}), 28.42$ (methyl group in cyclohexanone ring), 97.43 (C-2 of cyclohexanone), 162.14 (C-3 of cyclohexanone), 43.48 (C-4 of cyclohexanone), 32.95 (C-5 of cyclohexanone), 51.25 (C-6 of cyclohexanone),117.71-142.53 (Aromatic carbons).

DMPC-3 (5,5-dimethyl-3-(4-bromophenylamino)cyclohex-2-enone): $\quad$ Yield 71\%, M.P $238^{\circ} \mathrm{C}$, Molecular Formula $\mathrm{C}_{14} \mathrm{H}_{16} \mathrm{NOBr}$; \%Calcd. (Found); $\mathrm{C} \%=57.18$ (57.16), $\mathrm{H} \%=5.38$ (5.48), $\mathrm{N} \%=4.78$ (4.76) $\mathrm{O} \%=5.42$ (5.44), Br\%= 27.14 (27.16). M/z (M) +:350,352; FT-IR $\left(\mathrm{KBr}, \mathrm{cm}^{-1}\right): 3066.11 \mathrm{~cm}^{-1}$ (Aromatic $\mathrm{CH}$ stretching), $2885.51 \mathrm{~cm}^{-1}$ (Aliphatic $\mathrm{CH}$ stretching), $1658.78 \mathrm{~cm}^{-1}$ (Amide $\mathrm{C}=\mathrm{O}$ stretching), $1417.68 \mathrm{~cm}^{-1}(\mathrm{C}=\mathrm{N}$ Stretching), 642.3, 709.8, 763.81 $\mathrm{cm}^{-1}$ (Aromatic ring stretching); ${ }^{1} \mathrm{H}$ NMR $\left(\mathrm{CDCl}_{3}, \delta \mathrm{ppm}, 400 \mathrm{MHz}\right) 1.06-1.48\left(\mathrm{~m}, 6 \mathrm{H}\right.$ of $\left.\mathrm{CH}_{3}\right)$, 2.18-2.58 (m, $4 \mathrm{H}$ of methylene in cyclohexanone), $3.12(\mathrm{~S}, 1 \mathrm{H}$ of $\mathrm{NH}), 5.76(\mathrm{~d}, 1 \mathrm{H}$ of $\mathrm{C}-2$ of cyclohexanone), 6.97-7.53(Aromatic protons); $\left.{ }^{13} \mathrm{C} \mathrm{NMR} \mathrm{(} \mathrm{CDCl}_{3}, \delta \mathrm{ppm}, 100 \mathrm{MHz}\right): 198.52$ $(\mathrm{C}=\mathrm{O}), 28.61$ (methyl group in cyclohexanone ring), 97.56 (C-2 of cyclohexanone), 162.84 (C3 of cyclohexanone), 43.38 (C-4 of cyclohexanone), 33.09 (C-5 of cyclohexanone), 50.73 (C6 of cyclohexanone),124.28-138.93 (Aromatic carbons).

DMPC-4 (5,5-dimethyl-3-(4-nitrophenylamino)cyclohex-2-enone): Yield 78\%, M.P $284^{\circ} \mathrm{C}$, Molecular Formula $\mathrm{C}_{14} \mathrm{H}_{16} \mathrm{~N}_{2} \mathrm{O}_{3}$; \%Calcd. (Found); $\mathrm{C} \%=64.42$ (64.60), $\mathrm{H} \%=6.28$ (6.20), N\% $=10.80(10.76) \mathrm{O} \%=18.39$ (18.44). M/z (M) +: 260.12; FT-IR $\left(\mathrm{KBr}, \mathrm{cm}^{-1}\right): 3065.23 \mathrm{~cm}^{-}$ ${ }^{1}$ (Aromatic CH stretching), $2881.74 \mathrm{~cm}^{-1}$ (Aliphatic $\mathrm{CH}$ stretching), $1657.15 \mathrm{~cm}^{-1}$ (Amide $\mathrm{C}=\mathrm{O}$ stretching), $1417.88 \mathrm{~cm}^{-1}\left(\mathrm{C}=\mathrm{N}\right.$ Stretching), 652.30, 712.57, $788.99 \mathrm{~cm}^{-1}$ (Aromatic ring stretching); ${ }^{1} \mathrm{H}$ NMR $\left(\mathrm{CDCl}_{3}, \delta\right.$ ppm, $\left.400 \mathrm{MHz}\right)$ 1.04-1.50 (m, $6 \mathrm{H}$ of $\left.\mathrm{CH}_{3}\right), 2.14-2.64(\mathrm{~m}, 4 \mathrm{H}$ of methylene in cyclohexanone), 3.09 ( $\mathrm{S}, 1 \mathrm{H}$ of $\mathrm{NH}), 5.48$ (d, 1H of C-2 of cyclohexanone), 6.72-7.94 (Aromatic protons); ${ }^{13} \mathrm{C} \mathrm{NMR}\left(\mathrm{CDCl}_{3}, \delta \mathrm{ppm}, 100 \mathrm{MHz}\right): 198.95(\mathrm{C}=\mathrm{O}), 29.05$ (methyl group in cyclohexanone ring), 98.18 (C-2 of cyclohexanone), 162.23 (C-3 of cyclohexanone), 43.14 (C-4 of cyclohexanone), 32.89 (C-5 of cyclohexanone), 50.83 (C-6 of cyclohexanone), 121.92-146.88 (Aromatic carbons).

DMPC-5 (5,5-dimethyl-3-(2-nitrophenylamino)cyclohex-2-enone): Yield 76\%, M.P $283^{\circ} \mathrm{C}$, Molecular Formula $\mathrm{C}_{14} \mathrm{H}_{16} \mathrm{~N}_{2} \mathrm{O}_{3}$; \%Calcd. (Found); $\mathrm{C} \%=64.48$ (64.60), $\mathrm{H} \%=6.28$ (6.20), $\mathrm{N} \%$ $=10.78$ (10.76) $\mathrm{O} \%=18.40(18.44)$; FT-IR $\left(\mathrm{KBr}, \mathrm{cm}^{-1}\right): 3065.47 \mathrm{~cm}^{-1}($ Aromatic $\mathrm{CH}$ stretching), $2882.12 \mathrm{~cm}^{-1}$ (Aliphatic $\mathrm{CH}$ stretching), $1657.85 \mathrm{~cm}^{-1}$ (Amide $\mathrm{C}=\mathrm{O}$ stretching), $1417.56 \mathrm{~cm}^{-1}\left(\mathrm{C}=\mathrm{N}\right.$ Stretching), 653.03, 713.61, $785.96 \mathrm{~cm}^{-1}$ (Aromatic ring stretching); ${ }^{1} \mathrm{H}$ NMR $\left(\mathrm{CDCl}_{3}, \delta \mathrm{ppm}, 400 \mathrm{MHz}\right) 1.05-1.56\left(\mathrm{~m}, 6 \mathrm{H}\right.$ of $\left.\mathrm{CH}_{3}\right), 2.09-2.46(\mathrm{~m}, 4 \mathrm{H}$ of methylene in cyclohexanone), $3.11(\mathrm{~S}, 1 \mathrm{H}$ of $\mathrm{NH}), 5.45$ (d, 1H of $\mathrm{C}-2$ of cyclohexanone), 6.74-7.96 (Aromatic protons); ${ }^{13} \mathrm{C} \mathrm{NMR}\left(\mathrm{CDCl}_{3}, \delta \mathrm{ppm}, 100 \mathrm{MHz}\right)$ : $198.91(\mathrm{C}=\mathrm{O}), 29.12$ (methyl group in cyclohexanone ring), 98.16 (C-2 of cyclohexanone), 162.24 (C-3 of cyclohexanone), 43.18 
(C-4 of cyclohexanone), 32.91 (C-5 of cyclohexanone), 50.85 (C-6 of cyclohexanone),121.98145.93 (Aromatic carbons).

\subsection{Molecular docking studies.}

The molecular docking studies of the synthesized compounds are done using the software Auto dock tool. The low value of B.S. (Binding Score) shows excellent activity against bacterial strains. All the DMPC compounds subjected to 1UAG (UDP-NACETYLMURAMOYL-L_ALANINE:D-GLUTAMATE LIGASE) MurD Protein, which is involved in the cell wall mechanism derived from E. coli (gram-negative) strain and 1JIJ (crystal structure of $S$. aureus complex with SB-239629) protein derived from S. aureus (grampositive) bacterial strain.

\subsection{IUAG.}

DMPC compounds showed notable binding scores compared with standard. The compounds DMPC-4,5 showed B.S. $-7.5 \mathrm{~kJ} / \mathrm{mol}$, the nearer interaction score with standard drug. Other than DMPC-1 has a good B.S. value $-6.8 \mathrm{~kJ} / \mathrm{mol}$. All the compounds have significant hydrogen bond interactions and hydrophobic interaction. The compound DMPC-4 has four hydrogen bond interactions with the amino acid residues TYR A: 180, TYR A: 36, LYS A: 84, and ASP A: 40. The compounds DMPC-3, 5 have three hydrogen bond interactions and one hydrophobic interaction. This docking result exhibit that the DMPC compounds may follow the cell wall mechanism on bacterial strains. The docking results of DMPC compounds with 1 UAG bacterial protein given in Table 1.

Table 1. The docking results of DMPC compounds with 1 UAG bacterial protein.

\begin{tabular}{l|c|c|c|c|c} 
Compound & B.S & HBI-bond length & HBI & HPI- bond length & HPI \\
\hline DMPC-1 & -6.8 & 2.29 & SER A: 264 & 5.11 & HIS A:267 \\
\hline DMPC-2 & -6.2 & 2.93, & GLY A:332, & 4.39, & VAL A:335, \\
& & 2.22 & LEU A: 330 & 3.46, & LEU A: 339 \\
\hline DMPC-3 & -6.4 & 2.00, & LEU A: 416, & 5.38 & PHE A:422 \\
& & 2.10, & SER A: 415 & & \\
\hline DMPC-4 & -7.5 & $2.44,2.69$, & TYR A: 170, & 4.48, & HIS A: 50 \\
& & $2.70,2.47$, & TYR A: 36 & 4.43, & ALA A: 39 \\
& & 2.07 & LYS A:84 & 3.93 & \\
\hline DMPC-5 & -7.5 & 2.84, & TYR A:36, & 4.13 & LEU A: 70 \\
& & 2.15, & GLN A: 196 & & \\
\hline Ciprofloxacin & -7.7 & 3.03 & GLN A: 174 & & ALA A: 328
\end{tabular}

\section{4. $1 J I J$.}

The compounds docked with 1JIJ showed that all the compounds have fewer B.S. values than the standard drug. Only the compound DMPC-4 has the B.S. value $-8.4 \mathrm{~kJ} / \mathrm{mol}$ and four hydrogen bond interactions and two hydrophobic interactions. Other than the compound, DMPC-5 shows a good number of hydrogen bond interactions than the standard one. The docking result of DMPC compounds with 1JIJ showed that the DMPC compounds did not follow the mechanism of $1 \mathrm{JIJ}$ bacterial strain. The compounds literally follow the mechanism of 1JIJ; that's why the compounds have a less binding score with $1 \mathrm{JIJ}$. 


\subsection{ADME.}

All the target compounds DMPC has good ADME prediction values. The bioavailability score of all the compounds is 0.55 .

Mostly all the target compounds in-silico ADME values are satisfy the Lipinski rule of five. All the compounds should obey the Lipinski rule with 0 violations. The polar surface area value is high for DMPC-4 and DMPC-5 compounds rather than others in the series. The target compounds have solubility values in the range of -3 to -4 . All the compounds have the best absorption \% value. All the compounds exhibit acceptable ADME values, which are tabulated in Table 3.

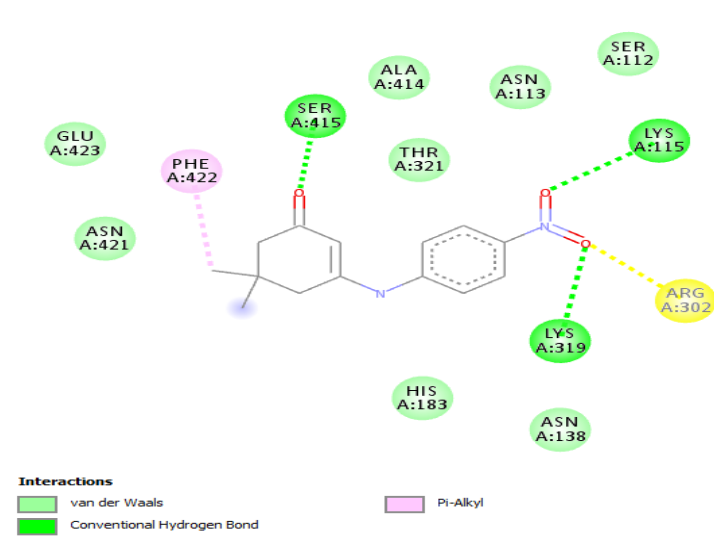

(a)
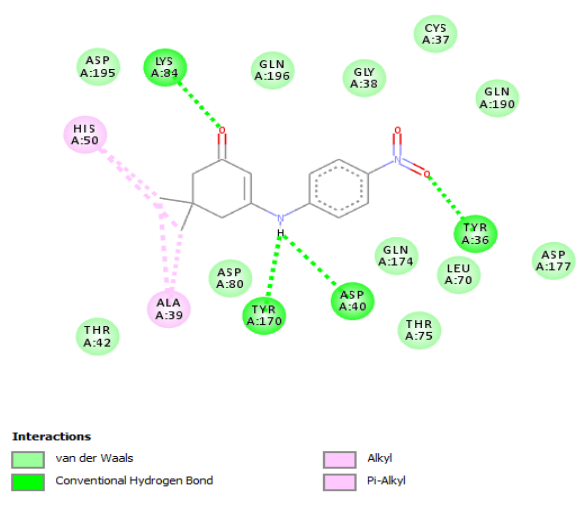

(c)

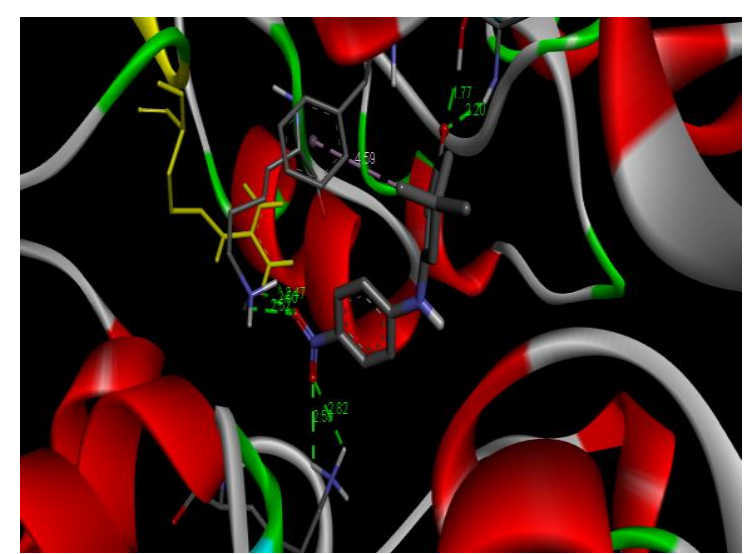

(b)

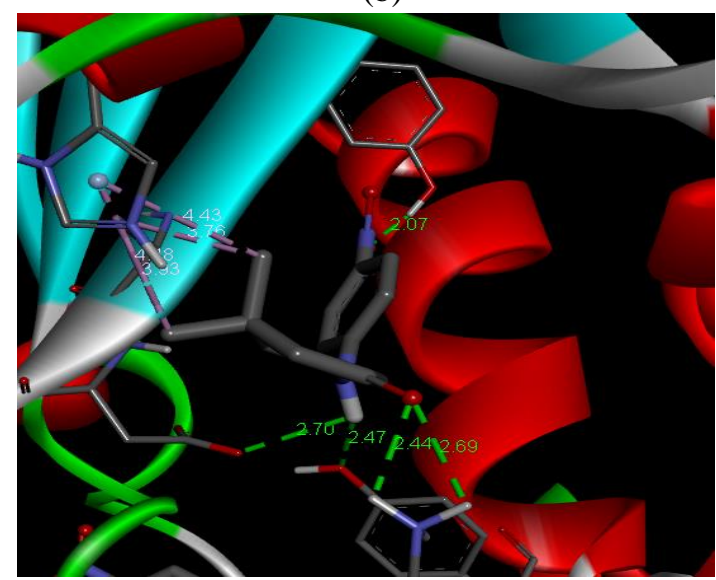

(d)

Figure 2. (a) 2D structure of DMPC-4 with 1 UAG protein, (b) 3D structure of DMPC-4 with 1UAG protein, (c) 2D structure of DMPC-4 with 1JIJ protein (d) structure of DMPC-4 with 1JIJ protein.

Table 2. The docking result of DMPC compounds with $1 \mathrm{JIJ}$ bacterial protein.

\begin{tabular}{l|l|l|l|l|l} 
Compound & B.S & HBI-bond length & HBI & HPI- bond length & HPI \\
\hline DMPC-1 & -6.7 & 3.05 & ARG A:12 & 5.09 & $\begin{array}{l}\text { PHE A: 273, } \\
\text { ARG A: 59 }\end{array}$ \\
\hline DMPC-2 & -7.0 & 2.32 & ASP A: 195 & 3.65, & LEU A: 52, \\
& & & & 4.94, & VAL A: 224, \\
& & & & 5.05 & PRO A: 53, \\
& & - & - & 4.62, & CYS A: 37 \\
\hline DMPC-3 & -6.8 & & & 5.16, & TYS A: 37 \\
& & & TY: 36 \\
& -8.4 & 2.07, & TYR A: 170 & 3.93, & HIS A: 50 \\
\hline DMPC-4 & & 2.44, & ASP A: 40 & 4.43, & ALA A: 39 \\
& & 2.47, & TYR A:36 & 4.48 & \\
& & 2.69, & TYR A: 36 & 4.13 & \\
\hline DMPC-5 & -7.9 & 2.70 & & & LEU A: 70
\end{tabular}




\begin{tabular}{l|l|l|l|l|l}
\hline \multirow{2}{*}{ Compound } & B.S & HBI-bond length & HBI & HPI- bond length & HPI \\
\hline & & 2.84 & GLN A:196 & & \\
\hline Ciprofloxacin & -9.5 & 3.03 & GLN A: 174 & & \\
& & 2.10 & TYR A: 36 & 4.56 & CYS A: 37 \\
& & 2.32 & THR A: 75 & &
\end{tabular}

Table 3. ADME prediction values of DMPC compounds.

\begin{tabular}{l|c|c|c|c|c|c|c|c|c} 
Compound & Formula & $\begin{array}{c}\text { Molecular } \\
\text { Weight }\end{array}$ & $\begin{array}{c}\text { H-bond } \\
\text { donors }\end{array}$ & $\begin{array}{c}\text { H-bond } \\
\text { acceptors }\end{array}$ & $\begin{array}{c}\text { Molecular } \\
\text { Refractivity }\end{array}$ & TPSA & $\begin{array}{c}\text { \% of } \\
\text { Abs }\end{array}$ & $\begin{array}{c}\text { Log } \\
\text { S }\end{array}$ & $\begin{array}{c}\text { Log } \\
\text { P }\end{array}$ \\
\hline DMPC-1 & $\mathrm{C}_{14} \mathrm{H}_{17} \mathrm{NO}$ & 215.29 & 1 & 1 & 66.75 & 29.1 & 98.96 & -3.27 & 2.37 \\
\hline DMPC-2 & $\mathrm{C}_{14} \mathrm{H}_{16} \mathrm{ClNO}$ & 249.74 & 1 & 1 & 71.76 & 29.1 & 98.96 & -3.92 & 2.9 \\
\hline DMPC-3 & $\mathrm{C}_{14} \mathrm{H}_{16} \mathrm{BrNO}$ & 294.19 & 1 & 1 & 74.45 & 29.1 & 98.96 & -3.98 & 3.02 \\
\hline DMPC-4 & $\mathrm{C}_{14} \mathrm{H}_{16} \mathrm{~N}_{2} \mathrm{O}_{3}$ & 260.29 & 1 & 3 & 75.57 & 74.92 & 83.15 & -4.62 & 1.2 \\
\hline DMPC-5 & $\mathrm{C}_{14} \mathrm{H}_{16} \mathrm{~N}_{2} \mathrm{O}_{3}$ & 260.29 & 1 & 3 & 75.57 & 74.92 & 83.15 & -4.05 & 1.2
\end{tabular}

Acceptable values: n-Heavy atoms, MW<500, Log P $<5$, n-HyA $\leq 10, n-H y D \leq 5$, M.Rty $<120, \log \mathrm{S} \leq-5$, TPSA $(30 \leq$ to $\geq 140$ ), Drug Score $\geq 0.5, \% A b s$ ( $\leq 80 \%$ (best), $30-80$ (moderate), $\geq 30 \%$ (poor)).

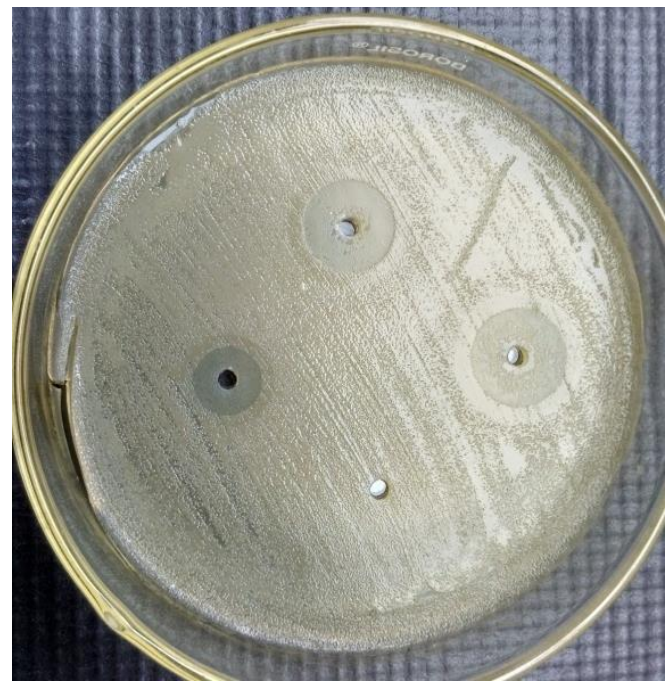

(a)

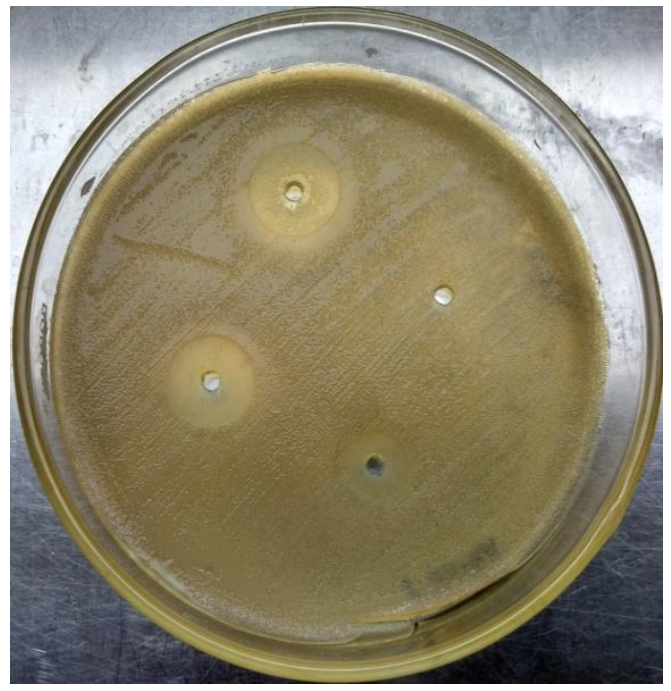

(c)

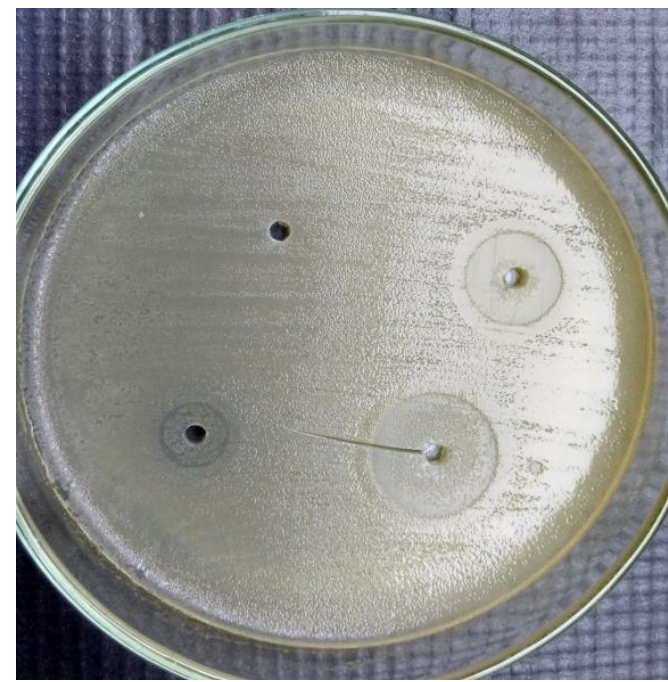

(b)

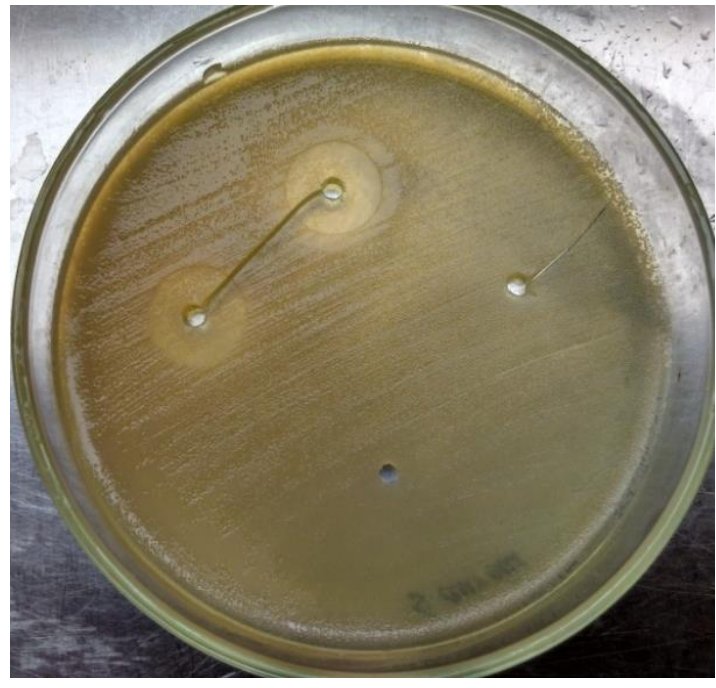

(d)

Figure 3. (a) in-vitro studies result (a) bacterial strain of the compound DMPC-4 averse to E. coli, (b) bacterial strain of the compound DMPC-5 averse to E. coli, (c) bacterial strain of the compound DMPC-4 averse to $S$. aureus, (d) bacterial strain of the compound DMPC-5 averse to S. aureus. 


\subsection{Anti-bacterial study.}

The synthesized compounds are screened with bacterial strains at $2.5,5$ and $10 \mu \mathrm{g} / \mathrm{mL}$. For the anti-bacterial study, use the one gram-negative strain E. coli and one gram-positive strain $S$. aureus with three different concentrations. Overall, the study showed that the DMPC compounds have a good inhibition zone level when treated with $E$. coli than the treat with $S$. aureus. The DMPC compounds may have the best active against gram-negative bacteria than that the gram-positive bacteria. The DMPC-1,3 compounds have a noticeable zone of inhibition values compared with the standard drug. The zone of inhibition values of DMPC compounds with E.coli and S.aureus bacterial strains at different concentrations are given in Table 4 and Figure 3.

Table 4. Antimicrobial studies of DMPC1-5

\begin{tabular}{l|c|c|c|c|c|c}
\multirow{2}{*}{ Sample } & \multicolumn{6}{|c}{ Zone of Inibition (diameter in mm) } \\
\cline { 2 - 7 } & \multicolumn{7}{|c}{ E.coli } & \multicolumn{3}{c}{ S.aureus } \\
\cline { 2 - 7 } & $10 \mu \mathrm{g} / \mathrm{mL}$ & $5 \mu \mathrm{g} / \mathrm{mL}$ & $2.5 \mu \mathrm{g} / \mathrm{mL}$ & $10 \mu \mathrm{g} / \mathrm{mL}$ & $5 \mu \mathrm{g} / \mathrm{mL}$ & $2.5 \mu \mathrm{g} / \mathrm{mL}$ \\
\hline DMPC-1 & 20 & 18 & 12 & 15 & 13 & 11 \\
\hline DMPC-2 & 15 & 12 & 10 & 19 & 16 & 12 \\
\hline DMPC-3 & 18 & 16 & 14 & 14 & 12 & 10 \\
\hline DMPC-4 & 16 & 14 & 10 & 16 & 14 & 13 \\
\hline DMPC-5 & 15 & 13 & 12 & 16 & 14 & 12 \\
\hline Ciprofloxacin & 28 & 22 & 19 & 38 & 32 & 26
\end{tabular}

3.7. Recover and reuse of catalyst.

The catalyst $\left(\mathrm{NaHSO}_{4}-\mathrm{SiO}_{2}\right)$ was recovered from the reaction mixture and reused by washed with acetone, filtered, dried, and activated. The catalyst was very efficient to 5 cycles of reaction carried out. So, that up to 5 cycles, the catalyst was collected and reused. The compared values up to five runs the yield are more or less similar rate. There is no wide change in the yield of synthesized compounds DMPC (1-5). The following graph represents the compared yield of compounds during reaction cycles.

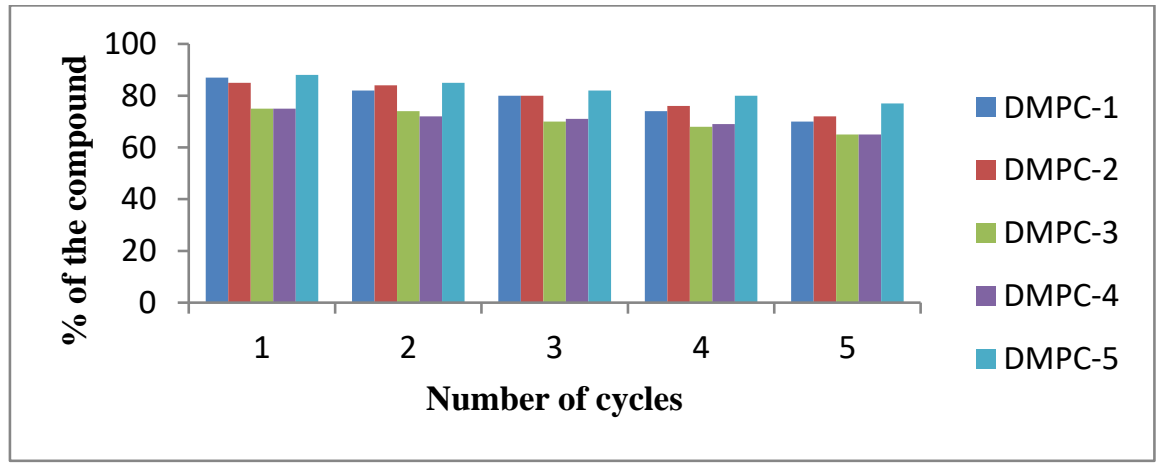

Figure 2. Recovery and reuse of the heterogeneous catalyst $\mathrm{NaHSO}_{4}-\mathrm{SiO}_{2}$.

\section{Conclusions}

The DMPC 1-5 compounds were successfully synthesized by using re-useable sodium bisulfate as a catalyst with the help of a microwave. The catalyst was reused up to five cycles of every targeted compound's synthesis reactions and indicates that the $\mathrm{NaHSO}_{4}-\mathrm{SiO}_{2}$ has a highly effective catalyst in a dry media synthesis of DMPC compounds. The compounds' skeleton structure is characterized and confirmed from the IR, ${ }^{1} \mathrm{H}$ NMR, and ${ }^{13} \mathrm{C}$ NMR values. The compounds are subjected to docking studies and ADME studies. All the compounds have acceptable values in the ADME studies. From docking studies, all the DMPC compounds may 
follow the cell-wall synthesis against bacterial strains. All have good binding interaction with IUAG than 1JIJ. The in-vitro anti-bacterial studies also showed that the DMPC compound good active against gram-negative $E$. coli than the gram-positive $S$. aureus.

\section{Funding}

This research received no external funding.

\section{Acknowledgments}

This research has no acknowledgment.

\section{Conflicts of Interest}

The authors declare no conflict of interest.

\section{References}

1. Andrade, C.; Andrade, Z.; De, A.; Barreto, F.; Silva, W. Microwave assisted solvent-, support-and catalyst-free synthesis of enaminones. ARKIVOC: archive for organic chemistry 2008, 2008, 226-232, https://doi.org/10.3998/ARK.5550190.0009.C24.

2. Kappe, C.O. Controlled Microwave Heating in Modern Organic Synthesis. Angewandte Chemie International Edition 2004, 43, 6250-6284. https://doi.org/10.1002/anie.200400655

3. Rajender, S.V. Solvent-free accelerated organic syntheses using microwaves. Pure and Applied Chemistry 2001, 73, 193-198, https://doi.org/10.1351/pac200173010193.

4. Seijas, J.A.; Vázquez-Tato, M.P.; Crecente-Campo, J. Microwave-Assisted Solvent-Free Synthesis of Enol Carbamates. Synlett 2007, 2007, 2420-2424,https://doi.org/10.1055/s-2007-985607.

5. Braibante, H.T.S.; Braibante, M.E.F.; Rosso, G.B.; Oriques, D.A. Preparation of b-enamino carbonylic compounds using microwave radiation/K-10. Journal of the Brazilian Chemical Society2003, 14, 994997, https://doi.org/10.1590/S0103-50532003000600016.

6. Braibante, M.E.F.; Braibante, H.T.S.; Morel, A.F.; Costa, C.C.; Lima, M.G. The solvent free preparation of b-amino esters a,b-unsaturated ketones and esters with domestic microwave oven.Journal of the Brazilian Chemical Society2006, 17, 184-188, https://doi.org/10.1590/S0103-50532006000100026.

7. Das, B.; Venkateswarlu, K.; Majhi, A.; Reddy, M.R.; Reddy, K.N.; Rao, Y.K.; Ravikumar, K.; Sridhar, B. Highly efficient, mild and chemo- and stereoselective synthesis of enaminones and enamino esters using silica supported perchloric acid under solvent-free conditions. Journal of Molecular Catalysis A: Chemical 2006, 246, 276-281, https://doi.org/10.1016/j.molcata.2005.11.045.

8. Timur, M.; Kavak, G.; Şenöz, H.; İde, S.; Tunoğlu, N. Synthesis, Crystallographic and Spectral Studies of 3-(4-(Phenylamino) Phenylamino)Cyclohex-2-Enone. Journal of Chemical Crystallography 2010, 40, 376-380, https://doi.org/10.1007/s10870-009-9664-3.

9. Venkov, A.P.; Angelov, P.A. Synthesis of Unsymmetrical $\beta$-Enamino Ketones. Synthesis 2003, 2003, 2221-2225, https://doi.org/10.1055/s-2003-41067.

10. Elassar, A.-Z.A.; El-Khair, A.A. Recent developments in the chemistry of enaminones. Tetrahedron 2003, 59, 8463-8480, https://doi.org/10.1016/S0040-4020(03)01201-8.

11. Ivanov, I.; Nikolova, S.; Angelov, P.; statkova-abeghe, S.; Kochovska, E. Regioselective acylation of $\beta$ enaminones of homoveratrylamine. General Papers ARKIVOC 2007, 2007, 11-17, https://doi.org/10.3998/ark.5550190.0008.f02.

12. Cindrić, M.; Vrdoljak, V.; Strukan, N.; Brbot-Šaranović, A.; Novak, P.; Kamenar, B. The new molybdenum(V) complexes with differently $\mathrm{N}$-substituted $\beta^{\prime}$-hydroxy- $\beta$-enaminones. Inorganica Chimica Acta 2004, 357, 931-938, https://doi.org/10.1016/j.ica.2003.09.034.

13. Shi, Y.C. 3-[(2-hydroxyphenyl)amino]-1-phenylbut-3-en-1-one ethanol solvate.Acta Crystallogr Sect E Struct. Comm.2005, E61, o1130-o1132, https://doi.org/10.1107/S1600536805008925.

14. El-hashim, A.Z.; Edafiogho, I.O.; Kombian, S.B.; Yousif, M.H.2007, US Patent 0167518 A1.

15. Fonseca, T.L.; de Oliveira, H.C.B.; Amaral, O.A.V.; Castro, M.A. MP2 static first hyperpolarizability of azo-enaminone isomers. Chemical Physics Letters 2005, 413, 356-361, https://doi.org/10.1016/j.cplett.2005.08.007.

16. Cox, D.S.; Scott, K.R.; Gao, H.; Eddington, N.D. Effect of P-Glycoprotein on the Pharmacokinetics and Tissue Distribution of Enaminone Anticonvulsants: Analysis by Population and Physiological Approaches. Journal of Pharmacology and Experimental Therapeutics 2002, 302, 1096-1104, https://doi.org/10.1124/jpet.102.035436. 
17. Ananthalakshmi, K.V.V.; Edafiogho, I.O.; Kombian, S.B. Concentration-dependent effects of anticonvulsant enaminone methyl 4-(4'-bromophenyl)aminocyclohex-3-en-6-methyl-2-oxo-1-oate on neuronal excitability in vitro. Neuroscience 2006, 141, 345-356, https://doi.org/10.1016/j.neuroscience.2006.03.021.

18. Khosropour, A.R.; Khodaei, M.M.; Kookhazadeh, M. A mild, efficient and environmentally friendly method for the regio- and chemoselective synthesis of enaminones using Bi(TFA)3 as a reusable catalyst in aqueous media. Tetrahedron Letters 2004, 45, 1725-1728, https://doi.org/10.1016/j.tetlet.2003.12.093.

19. Abass, M.; Mostafa, B.B. Synthesis and evaluation of molluscicidal and larvicidal activities of some novel enaminones derived from 4-hydroxyquinolinones: Part IX. Bioorganic \& Medicinal Chemistry 2005, 13, 6133-6144, https://doi.org/10.1016/j.bmc.2005.06.038.

20. Lenin, R.; Madhusudhan, R. Lanthanum trichloride: An efficient Lewis acid catalyst for chemo and regioselective enamination of $\beta$-dicarbonyl compounds. Arkivoc 2007, 2007, 204-209, http://dx.doi.org/10.3998/ark.5550190.0008.d23.

21. Cimarelli, C.; Palmieri, G.; Volpini, E. An Improved Synthesis Of Enantiopure B-Amino Acids. Synthetic Communications 2001, 31, 2943-2953, https://doi.org/10.1081/SCC-100105666.

22. Renjith Thomas, Y.; Sheena Mary, K.S.; Resmi, B.; Narayana, S.B.K.; Stevan Armakovic; Sanja, J.; Armakovic, G.; Vijayakumar, C.; Van Alsenov; Mohan, B.J. Synthesis and spectroscopic study of two new pyrazole derivatives with detailed computational evaluation of their reactivity and pharmaceutical potential, J. Molstruct. 2019, 1181, 599-612, https://doi.org/10.1016/j.molstruc.2019.01.014

23. Nagaiah, K.; Purnima, K.V.; Sreenu, D.; Jhansi, S.; Srinivasa Rao, R.; Yadav, J.S. Phosphomolybdic Acid (PMA) Catalyzed Highly Efficient and Rapid Synthesis of $\beta$-Enaminones. Synthetic Communications 2012, 42, 461-468, https://doi.org/10.1080/00397911.2010.524339.

24. Vibala, B.V.; Praseetha, P.K.; Vijayakumar, S. Evaluating new strategies for anticancer molecules from ethnic medicinal plants through in-silico and biological approach-A review, Gene Reports, 2020, 18, 100553, https://doi.org/10.1016/j.genrep.2019.100553

25. Mayur K. Vekariya; Dhaval B. Patel; Pranav A. Pandya; Rajesh H. Vekariya; Prapti U. Shah; Dhanji P. Rajani; Nisha K. Shah. Novel N-thioamide analogues of pyrazolylpyrimidine based piperazine: Design, synthesis, characterization, in-silico molecular docking study and biological evaluation. J. Molstruct. 2019, 1175, 551-565, https://doi.org/10.1016/j.molstruc.2018.08.018

26. Sharanya Kuthyala; Manjunatha Hanumanthappa; Madan Kumar, S.; Sana Shiek; Nagaraja Gundibasappa Kaikannar; Ashwini Prabhu. Crystal, Hirshfeld, ADMET, drug-like and anticancer study of some newly synthesized imidazopyridine containing pyrazoline derivatives, J. MolStruct. 2019, 1197, 65-72, https://doi.org/10.1016/j.molstruc.2019.07.031

27. Yousif, O.A.; Mahdi, M.F.; Raauf, A.R. Design, synthesis, preliminary pharmacological evaluation, molecular docking and ADME studies of some new pyrazoline, isoxazoline and pyrimidine derivatives bearing nabumetone moiety targeting cyclooxygenase enzyme. J.Contemp. Med. Sci.2019, 5, 41-50

28. Chinnamanayakar, R.; Ezhilarasi, M.R.; Prabha, B.; Kulandhaivel, M. in-vitro Antimicrobial and in silico Activity of 1-Thiocarbmoyl Substituted Pyrazole Derivatives.Asian J. of Chem.2018, 30, 783-789, https://doi.org/10.14233/ajchem.2018.20992.

29. Ali, A.R.; El-Bendary, E.R.; Ghaly, M.A.; Shehata, I.A. Synthesis, in vitro anticancer evaluation and in silico studies of novel imidazo[2,1-b]thiazole derivatives bearing pyrazole moieties. European Journal of Medicinal Chemistry 2014, 75, 492-500, https://doi.org/10.1016/j.ejmech.2013.12.010.

30. Mathew, M.; Chinnamanayakar, R.; Ramanathan, E. Synthesis, Characterization, in vitro Antimicrobial Evaluation and in silico Molecular Docking and ADME Prediction of 4-Chlorophenyl Furfuran Derivatives bearing Pyrazole Moieties. Asian Journal of Chemistry 2020, 32, 1482-1490, https://doi.org/10.14233/ajchem.2020.22634.

31. Prabha, B.; Raja, C.; Nathiya, S.; Ezhilarasi, M.R. Synthesis, in-vitro and in-silico Studies of Naphthalene Pyrazoline Prop-2-en-1-one Derivatives. Asian Journal of Chemistry. 2020, 32(8), 18491856. https://doi.org/10.14233/ajchem.2020.22654

32. Xing Zhang; Fan Qi; Sifan Wang; Jirong Song; Jie Huang. Synthesis, structure, in-silico ADME evaluation and in vitro antioxidant of (E)-N-(4-ethylphenyl)-2-(isomeric methylbenzylidene) $\begin{array}{lllll}\text { thiosemicarbazone } \quad \text { derivatives, } & \text { J.MolStruct. } & \mathbf{2 0 2 0}, & 1199, & 126972 .\end{array}$ https://doi.org/10.1016/j.molstruc.2019.126972

33. Özkınalı, S.; Gür, M.; Şener, N.; Alkın, S.; Çavuş, M.S. Synthesis of new azo schiff bases of pyrazole derivatives and their spectroscopic and theoretical investigations. Journal of Molecular Structure 2018, 1174, 74-83, https://doi.org/10.1016/j.molstruc.2018.06.070. 